\title{
How to Maintain Employee Motivation Amid The Covid-19 Virus Pandemic
}

\author{
Submitted 21/06/20, 1st revision 18/07/20, 2nd revision 20/08/20, accepted 15/09/20 \\ Christian Wiradendi Wolor ${ }^{1}$, Solikhah ${ }^{2}$, Dewi Susita ${ }^{3}$, S. Martono ${ }^{4}$
}

\begin{abstract}
:
Purpose: The main aim of this article is to broaden insights on how to keep motivating employees in working amid dangerous conditions, especially now with the outbreak of the Covid-19 virus by reviewing various existing literature and using qualitative methodologies to support this research..

Design/Methodology/Approach: This research is a systematic review using the PRISMA (Preferred Reporting Items for Systematic Reviews and Meta-analysis) method which is carried out systematically by following the correct stages or research protocols.

Findings: The results of our analysis are in the form of recommendations related to maintaining employee work motivation, namely work from home and work shifts.

Practical Implications: All organizations affected by the Covid-19 pandemic can take different approaches to maintain employee motivation in the workplace as working from home and working shifts.
\end{abstract}

Originality Value: This is the first paper which has analyzed employee motivation amid the Covid-19 virus pandemic

Keywords: Employee motivation, work from home, work shift, Covid-19.

JEL codes: J24, O15.

Paper Type: Research study.

\footnotetext{
${ }^{1}$ Lecturer, Faculty of Economics, Universitas Negeri Jakarta, christianwiradendi@unj.ac.id; 2Lecturer, Faculty of Economics, Universitas Negeri Jakarta, sholikhah@unj.ac.id 3Lecturer, Faculty of Economics, Universitas Negeri Jakarta, dewisusita man@unj.ac.id 4Lecturer, Faculty of Economics, Universitas Negeri Semarang, martono@mail.unnes.ac.id;
} 


\section{Introduction}

Currently, the whole world is being hit by concerns about the spread of the covid-19 virus that does not know the time and place. Amid the current outbreak of the covid19 virus, many workers must be closed, isolated or worked from home as directed by the local government to reduce the spread of this virus (Fachriansyah, 2020). However, there are still companies that continue to operate with a record of employee shifts or made virtual to keep getting income from the business. This is a challenge for the company facing the coronavirus pandemic on how to maintain employee motivation at work. Companies that continue to run their business amid the covid-19 virus outbreak should be equipped with a supply of masks and hand sanitizers to provide security to their employees, but the fact is that many workers, especially those in the lower classes are not equipped with safety equipment and extensive knowledge about the covid-19 virus (Syakriah, 2020a; Grima et al., 2020).

The Covid-19 virus was first discovered in China with the spread of this virus can be between humans and is currently developing throughout the world (Kampf, Todt, Pfaender, and Steinmann, 2020). So employees need to work from home or at a minimum if they keep working, they must be equipped with masks, physical distance and hand sanitizer policies to protect themselves so that they can cut off the spread of this virus (Desk, 2020).

Anxiety about this disease outbreak will negatively affect employee's motivation which affects the level of negative emotions that arise and will be difficult to maintain the performance of these employees (Assor, Kaplan, Kanat-maymon, and Roth, 2005). However, on the other hand, employees will be motivated to continue to act even if it is dangerous when it comes to life values especially their basic needs (Amiot, Sansfaçon, and Louis, 2013). As it is today, not a few people who have a low economic level to continue to work when the Covid-10 virus outbreak to support their daily needs (Amiot et al., 2013; Syakriah, 2020b). Organizational leaders can still motivate employees by providing various ways by relying on employee creativity and flexibility in carrying out their obligations as employees (Humala, 2017).

The purpose of this study is to broaden insights on how to keep motivating employees in working amid dangerous conditions, especially now with the outbreak of the Covid19 virus from reviewing various existing literature and using qualitative methodologies to support this research. Next, we present the results of our empirical analysis and discuss the implications of our research.

\section{Literature Review}

Work motivation is the desire that causes the person to take action (Slamet and Riyadi, 2011) to achieve the goal of meeting the needs or achieving balance (Wiradendi, Supriyati, and Purwana, 2019). There are several motivational theories at this time, this study uses motivation theory from Abraham H. Maslow as a reference in 
analyzing existing problems and providing several solutions for the company's recommendations.

Abraham H. Maslow's theory states that motivation is formed because of a hierarchy of needs. First, physiological needs, such as clothing, food, and shelter. Second, security needs, security is meant not only physical security but also psychologically and intellectually. Third, social needs, recognition of the existence and giving of appreciation for their dignity. Fourth, the need for prestige, that all people need recognition of their existence and status by others. Finally, the need for selfactualization in the sense of the availability of opportunities for someone to develop the potential contained in him/her so that it turns into real abilities (Maslow, 1954).

The essence of Maslow's theory is that human needs are arranged in a hierarchy, if needs at a lower level have been fulfilled or satisfied, then there will be needs at a higher level, and so on in their order. According to Maslow, every manager who wants to motivate his subordinates needs to understand the hierarchy of human needs because satisfying human needs continuously is the key to motivating employees so they want to work well (Maslow, 1954; Siagian, 2014).

\section{Methods}

This research is a systematic review using the PRISMA (Preferred Reporting Items for Systematic Reviews and Meta-analysis) method which is carried out systematically by following the correct stages or research protocols. A systematic review is a research method that aims to evaluate, identify, analyze all previous research results that are related and relevant to a particular topic, particular research, or the latest phenomenon of concern (Perry and Hammond, 2002; Wolor, Pratama, Aditya, and Purwana, 2020). The facts presented are comprehensive and balanced because systematic reviews are used to synthesize relevant research findings. Qualitative systematic review includes the following steps: Formulating research questions, conducting systematic literature review searches, screening and selecting suitable research articles, conduct analysis and synthesis of qualitative findings, implement quality control, prepare a final report (Perry and Hammond, 2002; Wolor et al., 2020).

A qualitative approach is used to frame, analyze, and provide comprehensive solutions in maintaining employee motivation amid the pandemic Covid-19 virus (Berkah and Sawarjuwono, 2019). Various scientific articles are taken from specialized journals to help build the most prominent elements in describing work motivation in a dangerous environment, based on several important points explained by different authors (Moreno, Lafuente, Carreón, and Moreno, 2017).

\section{Discussion}


Employees will be motivated to work and perform well in the company where they work if their safety is thought of by the company (Christian, Bradley, Wallace, and Burke, 2009; Mensah and Tawiah, 2016). If this is not thought about, then there is anxiety that is felt by the employee and there is a feeling of discomfort at work (O'Rourke, Smith, Smoll, and Cumming, 2011). Companies that dare to make policies and decisions to provide security for employees are very important to keep growing positive motivation from their employees, especially amid the pandemic Covid-19 virus (Anderson, Baur, Grif, and Buckley, 2016; Balda and Mora, 2017). Therefore, the organization becomes a central role in increasing the motivation of its employees in completing their work and a sense of security for employees (Eisenberg and Krishnan, 2018; Martins, Gilson, and Maynard, 2004).

Companies can play an important role in accommodating the operational needs of the company amid the Covid-19 virus outbreak by providing extrinsic motivation. Extrinsic motivation in the form of tangible rewards as short-term is given to employees for example with overtime pay, compensation for coming to work directly in the middle of this pandemic. However, it should be interpreted for companies that extrinsic motivation does not last long and will endanger companies such as turn over, absenteeism, low performance, especially with this pandemic. Next, employees need to have intrinsic motivation where their achievements and work are recognized by the company (Cameron, Banko, and Pierce, 2001; May, Li, Mencl, and Huang, 2014; Reitman, 1998).

Based on Maslow's motivation theory there are 5 hierarchies of human needs namely physiological, security, social, prestige, self-actualization needs (Maslow, 1954). The three requirements above regarding social, prestige, and self-actualization will not be considered by employees amid the outbreak of Covid-19 virus due to policies regarding social distance and self-isolation to prevent transmission of the Covid-19 virus that can result in human death (Fachriansyah, 2020; Kampf et al., 2020; Syakriah, 2020b). Therefore, employees will focus on two basic needs regarding physiological needs related to food and daily needs and safety needs for employees at work. This is following Maslow's theory where if the needs at a lower level have been fulfilled or satisfied, there will be needs at a higher level (Maslow, 1954; Siagian, 2014). But what is happening right now is the need for security for employees that have not been fulfilled, so it will not be able to move to the needs above it.

In dealing with the condition of the Covid-19 virus outbreak this research will try to provide some recommendations related to maintaining employee motivation, namely:

Work from home: One thing that can be done is working from home that is working virtually which makes it easy and provides a sense of security for employees. Working from home, especially virtual, will make employees motivated because on one side they can feel there is a work-life balance (Felstead and Henseke, 2017; Humala, 2017; Robey, Schwaig, and Jin, 2003). But on the other hand, there is a decrease in interpersonal contact, feelings of isolation, and a high chance of misunderstanding 
(Morley, Cormican, and Folan, 2015). This needs to be a concern for leaders. Because this will reduce their motivation because they do not meet face to face, do not know directly their emotions, and do not receive enough help from them directly (Geister and Hertel, 2006; Humala, 2017). One solution to reduce the motivation reduction of employees related to working virtually can be done by video conferencing that is not just a text message such as email (Humala, 2017; Raghuram, Hill, Gibbs, and Maruping, 2019; Verburg, Bosch-Sijtsema, and Vartiainen, 2013). In applying the work form, several things must be observed by the company leadership, namely:

First, managerial support implemented through company policies and regulations in facilitating the implementation of work from home can increase employee's motivation. Employees feel safe, comfortable, and protected by company policies and regulations (Morley et al., 2015; Verburg et al., 2013). One form can be applied to the latest operating procedure standards, the latest work assessment and balanced also by continuing to appreciate the virtual presence and compensation to employees in maintaining the productivity rhythm of the employees themselves (Morley et al., 2015; Robey et al., 2003).

Second, sharing information and maintaining effective communication between employees through technology in work from home will increase employee motivation in completing work (Raghuram et al., 2019). Because the challenge now is to work face-to-face, it will be easier to share knowledge and information compared to working virtual (Jones and Graham, 2015), then do not be selfish especially in the midst of the outbreak of the Covid-19 virus (Kaul, Pande, and Ahuja, 2017; Martins et al., 2004). Effective communication between employees and listening to each other's opinions even though virtually, will be able to increase employee motivation (Morley et al., 2015).

Work shifts: The application of work shifts can be done in industrial sectors that do not allow for virtual work such as manufacturing, distribution and shipping companies. This should be seriously considered for companies to run to employees amid the Covid-19 virus outbreak because the risk of the possibility of transmission of the Covid-19 virus will be greater when compared to working from home. In the implementation of work shifts several things need to be considered by the company, namely:

First, even though working shifts, is not recommended for companies to impose long shifts for employees especially amid this virus outbreak. This will threaten not only employee's motivation and low employee's performance, but also threaten safety for employees due to reduced employee endurance (Ackah, 2014; Ayed, Thulth, and Sayej, 2015). Designing an effective shift schedule with due regard to health and safety will increase employee motivation (Hooi and $\mathrm{Su}, 2017$ ). 
Second, the safety, safety and health factors of employees need to be considered by the company, namely the provision of personal safety equipment, masks, disinfectants, appeals to a healthy lifestyle starting from food, and regular exercise, especially at this time (Nea et al., 2017; Syakriah, 2020a).

Third, recognition and appreciation from the company for the work done by employees, especially those who dare to work in shifts in a pandemic situation like this, both intrinsically, namely appreciation, praise, company recognition or extrinsic compensation in the form of money (Hooi and Su, 2017; Shen and Dicker, 2008).

Fourth, there is good teamwork between colleagues while working at the current shift (Hooi and $\mathrm{Su}$, 2017). Helping each other when difficulties can improve emotional relationships between employees and motivate employees (Kaul et al., 2017; Martins et al., 2004).

\section{Conclusion}

Keep working is a choice that must be made by employees to continue to meet their daily needs. However, amid the Covid-19 pandemic virus, attention needs to be paid to employee's safety and security. The company must establish policies to support the safety and security of its employees while continuing the operations of the company. Through this article, we recommend two different approaches that companies must pay attention to maintaining employee motivation at work. First is work from home and work shifts.

\section{Limitations and Future Research}

This research is only based on a review of literature selected by the authors from various sources of literature available to help to provide recommendations to companies to keep the working motivation of employees even though they are in danger of a Covid-19 pandemic virus. This was taken because the author is currently undergoing a policy from the Indonesian government for self-isolation and working from home. Future research requires a broader method through direct interviews or with quantitative methods to increase the repertoire of knowledge.

\section{References:}

Ackah, D. 2014. The Impact of Motivation on Employee Performance in the Manufacturing Industry in Ghana. Global Journal of Management Studies and Researches, 1(5), 291310.

Amiot, C.E., Sansfaçon, S., Louis, W.R. 2013. Investigating the motivations underlying harmful social behaviors and the motivational nature of social norms. Journal of Applied Social Psychology, 43, 2146-2157. https://doi.org/10.1111/jasp.12167.

Anderson, H.J., Baur, J.E., Grif, J.A., Buckley, M.R. 2016. What works for you may not work for ( Gen ) Me: Limitations of present leadership theories for the new 
generation. The Leadership Quarterly, 1-16. https://doi.org/10.1016/j.leaqua.2016.08.001.

Assor, A., Kaplan, H., Kanat-maymon, Y., Roth, G. 2005. Directly controlling teacher behaviors as predictors of poor motivation and engagement in girls and boys : The role of anger and anxiety. Learning and Instruction, 15, 397-413. https://doi.org/10.1016/j.learninstruc.2005.07.008.

Ayed, A., Thulth, A.S., Sayej, S. 2015. Impact of Night Shift and Training Development Factors on Performance of Professional Nurses in North West Bank Governmental Hospitals. Journal of Education and Practice, 6(27), 50-61.

Balda, J.B., Mora, F. 2017. Adapting Leadership Theory and Practice For The Networked, Millennial Generation. Journal of Leadership Studies, 5(3). https://doi.org/10.1002/jls.20229.

Berkah, D., Sawarjuwono, T. 2019. Inheritance Wealth Distribution Model And Its Implication To Economy. Humanities \& Social Sciences Reviews, 7(3), 1-10. https://doi.org/https://doi.org/10.18510/hssr.2019.731

Cameron, J., Banko, K.M., Pierce, D. 2001. Pervasive Negative Effects of Rewards on Intrinsic Motivation: The Myth Continues. The Behavior Analyst, 24, 1-44.

Christian, M.S., Bradley, J.C., Wallace, J.C., Burke, M.J. 2009. Workplace Safety: A MetaAnalysis of the Roles of Person and Situation Factors. Journal of Applied Psychology, 94(5), 1103-1127. https://doi.org/10.1037/a0016172.

Desk, N. 2020. No lockdown for Indonesia, Jokowi insists as COVID-19 cases continue to rise. The Jakarta Post. Retrieved from https://www.thejakartapost.com/news/2020/03/24/no-lockdown-for-indonesia-jokowiinsists-as-covid-19-cases-continue-to-rise.html.

Eisenberg, J., Krishnan, A. 2018. Addressing Virtual Work Challenges: Learning From the Field Addressing Virtual Work Challenges: Learning From the Field. Organization Management Journal, 15(2), 78-94. https://doi.org/10.1080/15416518.2018.1471976.

Fachriansyah, R. 2020. Work-from-home policy in effect at major Jakarta companies over virus concerns. The Jakarta Post. Retrieved from https://www.thejakartapost.com/news/2020/03/15/work-from-home-policy-in-effectat-major-jakarta-companies-over-virus-concerns.html.

Felstead, A., Henseke, G. 2017. Assessing the growth of remote working and its consequences for effort, well-being and work-life balance. New Technology, Work and Employment, 195-212. https://doi.org/10.1111/ntwe.12097.

Geister, S., Hertel, G. 2006. Effects of Process Feedback on Motivation, Satisfaction, and Performance in Virtual Teams. Small Group Research, 37(5), 459-489. https://doi.org/10.1177/1046496406292337.

Grima, S., Dalli Gonzi, R., Thalassinos, I.E. 2020. The Impact of COVID-19 on Malta and its Economy and Sustainable Strategies. Available at SSRN: https://ssrn.com/abstract=3644833 or http://dx.doi.org/10.2139/ssrn.3644833.

Hooi, L.W., Su, A.S.Y. 2017. Motivational factors of shift workers in the chemical industry in Malaysia. Int. J. Management Practice, 4(2). https://doi.org/10.1504/IJMP.2010.033692.

Humala, I. 2017. Typology On Leadership Toward Creativity In Virtual Work. Interdisciplinary Journal of Information, Knowledge, and Management, 12, 209-243.

Jones, N.B., Graham, C.M. 2015. Virtual Teams in Business and Distance Education: Reflections from an MBA Class. Journal of Business \& Economic Policy, 2(1), 49-59.

Kampf, G., Todt, D., Pfaender, S., Steinmann, E. 2020. Persistence of coronaviruses on inanimate surfaces and their inactivation with biocidal agents. Journal of Hospital 
Infection, 104(3), 246-251. https://doi.org/10.1016/j.jhin.2020.01.022.

Kaul, S., Pande, N., Ahuja, V. 2017. Virtual Team Effectiveness: An Empirical Study Using SEM. Procedia Computer Science, 122, 33-41. https://doi.org/10.1016/j.procs.2017.11.338.

Martins, L.L., Gilson, L.L., Maynard, M.T. 2004. Virtual Teams: What Do We Know and Where Do We Go From Here? Journal of Management, 30(6), 805-835. https://doi.org/10.1016/j.jm.2004.05.002.

Maslow, A.H. 1954. Motivation and Personality. Harper \& Row.

May, D.R., Li, C., Mencl, J., Huang, C.C. 2014. The Ethics of Meaningful Work: Types and Magnitude of Job-Related Harm and the Ethical Decision-Making Process The Ethics of Meaningful Work: Types and Magnitude of Job-Related Harm and the Ethical Decision-Making Process. J. Bus. Ethics, 121(4), 651-669. https://doi.org/10.1007/s.

Mensah, E.B.K., Tawiah, K.A. 2016. Employee Motivation and Work Performance: A Comparative Study of Mining Companies in Ghana. Journal of Industrial Engineering and Management, 9(2), 255-309. https://doi.org/http://dx.doi.org/10.3926/jiem.1530.

Moreno, F.M., Lafuente, J.G., Carreón, F.Á., Moreno, S.M. 2017. The Characterization of the Millennials and Their Buying Behavior. International Journal of Marketing Studies, 9(5), 135-144. https://doi.org/10.5539/ijms.v9n5p135.

Morley, S., Cormican, K., Folan, P. 2015. An Analysis of Virtual Team Characteristics: A Model for Virtual Project Managers. Journal of Technology Management \& Innovation, 10(1), 188-203.

Nea, F.M., Pourshahidi, L.K., Kearney, J., Livingstone, M.B.E., Bassul, C., Corish, C.A. 2017. A Qualitative Exploration of the Shift Work Experience The Perceived Barriers and Facilitators to a Healthier Lifestyle and the Role of the Workplace Environment. JOEM, 59(12). https://doi.org/10.1097/JOM.0000000000001126.

O’Rourke, D.J., Smith, R.E., Smoll, F.L., Cumming, S.P. 2011. Trait Anxiety in Young Athletes as a Function of Parental Pressure and Motivational Climate: Is Parental Pressure Always Harmful? Journal of Applied Sport and Psychology, (August 2010), 398-412. https://doi.org/10.1080/10413200.2011.552089.

Perry, A., Hammond, N. 2002. Systematic reviews: The experiences of a PhD student. Psychology Learning and Teaching, 2(1), 32-35.

Raghuram, S., Hill, N.S., Gibbs, J.L., Maruping, L.M. 2019. Virtual work: Bridging research clusters. Academy of Management Annals, 13(1), 1-34. https://doi.org/10.5465/annals.2017.0020.

Reitman, D. 1998. The real and imagined harmful effects of rewards: Implications for clinical practice. Journal of Behavior Therapy and Experimental Psychiatry, 29, (May 1997), 101-113.

Robey, D., Schwaig, K.S., Jin, L. 2003. Intertwining material and virtual work. Information and Organization, 13, 111-129. https://doi.org/10.1016/S1471-7727(02)00025-8.

Shen, J., Dicker, B. 2008. The impacts of shiftwork on employees. The International Journal of Human Resource Management, 19(2), 392-405. https://doi.org/10.1080/09585190701799978.

Siagian, S.P. 2014. Manajemen Sumber Daya Manusia. Jakarta: Bumi Aksara.

Slamet Riyadi. 2011. Pengaruh Kompensasi Finansial, Gaya Kepemimpinan, dan Motivasi Kerja Terhadap Kinerja Karyawan pada Perusahaan Manufaktur di Jawa Timur. Jurnal Manajemen Dan Kewirausahaan. https://doi.org/10.9744/jmk.13.1.40-45.

Syakriah, A. 2020a. What about us? Domestic workers feel neglected amid virus outbreak. The Jakarta Post. Retrieved from https://www.thejakartapost.com/news/2020/03/18/what-about-us-domestic-workers- 
feel-neglected-amid-virus-outbreak.html.

Syakriah, A. 2020b. Jakarta declares emergency, but doubts persist over compliance with social distancing directive. The Jakarta Post. Retrieved from https://www.thejakartapost.com/news/2020/03/22/jakarta-declares-emergency-butdoubts-persist-over-compliance-with-social-distancing-directive.html.

Verburg, R.M., Bosch-Sijtsema, P., Vartiainen, M. 2013. Getting it done: Critical success factors for project managers in virtual work settings. International Journal of Project Management, 31(1), 68-79. https://doi.org/10.1016/j.ijproman.2012.04.005.

Wiradendi, C., Supriyati, Y., Purwana, D. 2019. The Effect of Work Stress, Compensation and Motivation on the Performance of Sales People. International Journal of Innovation, Creativity and Change, 9(5), 252-269.

Wolor, C.W., Pratama, A., Aditya, S., Purwana, D. 2020. Adversity Quotient In Improving Millennial Generation Salespeople's Performance In The Industrial Revolution. Humanities \& Social Sciences Reviews, 8(1), 220-226. https://doi.org/https://doi.org/10.18510/hssr.2020.8131. 